\title{
CXCL14 Gene
}

National Cancer Institute

\section{Source}

National Cancer Institute. CXCL14 Gene. NCI Thesaurus. Code C24791.

This gene is involved in cellular homeostasis and chemotaxis. 